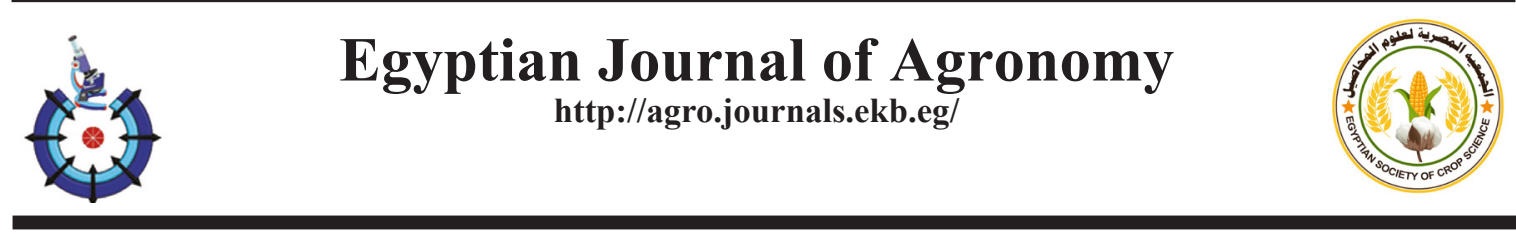

\title{
Response of Some Wheat Cultivars to Sowing Dates and Biofertilizers under North West Coast of Egypt
}

\author{
Ahmed M. Shaalan ${ }^{(1) \#}$, M.A. Attia(2), M.A. Hassaan ${ }^{(2)}$ \\ (1) Plant Production Department, Faculty of Desert and Environmental Agriculture, \\ Matrouh University, Matrouh, Egypt; (2)Department of Plant Production, Desert \\ Research Center, El-Matarrya, Cairo, Egypt.
}

\begin{abstract}
$\mathbf{T}$
WO FIELD experiments were conducted during 2016/2017 and 2017/2018 winter seasons at Fuka Research Station, Faculty of Desert and Environmental Agriculture, Matrouh University, Matrouh Governorate (North West Coast of Egypt, $N=31^{\circ} 04^{\prime}, E=27^{\circ} 54^{\prime}$ ). This work aimed to evaluate the response of three wheat (Triticum aestivum, L.) i.e.; Misr 2, Giza 168 and Sids 12 cultivars under three sowing dates $\left(15^{\text {th }}\right.$ November, $30^{\text {th }}$ November and $15^{\text {th }}$ December and three treatments of biofertilizer (Control, Blue green algae (BGA) "Gorn 19" and Micobine). A split-split plot design with three replicates was used in both seasons. The main plots were devoted to three wheat cultivars and the sub plots were occupied by the three sowing dates whereas, the sub-sub plots were assigned to the three biofertilizer treatment. Field experiment results indicated that under Matrouh condition, Sids 12 cultivar, gave higher values for plant height, No. of grains/spike, 100 grain weight, biological yield, grain yield and harvest index compare to other cultivars (Misr 2 and Giza 168). In addition, early sowing at Nov, 15 and using BGA as biofertilizer significantly increased all studied characters. Regression analysis for grain yield and yield components, results indicating that the highest effect for delayed sowing was detected for no. of spikes $/ \mathrm{m}^{2}(-1.37$ and -1.40$)$ while, the least effect was estimated for 100 grain weight $(-0.86$ and -1.54) for two seasons, respectively.
\end{abstract}

Keywords: Wheat, Sowing dates, Blue green algae, Microbein, Yield.

\section{Introduction}

Worldwide, wheat is the third most-produced cereal crop after maize and rice, according to its production, (FAO, 2018). In Egypt, wheat is the most important staple crop in the country and an essential component of the Egyptian diet. According to the Food and Agriculture Organization of the United Nations (FAO, 2018), the total planted area of wheat in Egypt is 1.37 million hectares with a total production of 9 million tons. The total wheat consumption in Egypt is around 19 million tons; this wide gap between consumption and actual production forces the country to import 10 million tons to close this gap. Increasing the acreage and productivity of wheat crop is a national necessity to overcome the shortage in wheat production compared to consumption (Milad et al., 2016).
Date of sowing is an important agriculture practice that is determined through the environmental requierments of the wheat crop (Shaaban et al., 2018). Early sowing at the recommended time results in increased productivity of wheat due to the prevalence of ideal conditions, i.e. temperature, rainfall etc. at that time (Ma et al., 2018). Generally, late sowing reduces $\mathrm{N}$ uptake and accumulation in wheat crops (Widdowson et al., 1987; Ehdaie \& Waines, 2001). Sowing date plays a vital role in yield potential of wheat production. Refay (2011) investigated the effect of early (November, 21 ${ }^{\text {st }}$ ) and late (December, 21 ${ }^{\text {st }}$ ) sowing on different wheat cultivars and lines under North Sinai conditions. His findings revealed that late sowing caused significant decease in grain yield (about $8 \%$ ) compared to early sowing. They also reported variable response for wheat genotype as affected by sowing date.

"Corresponding author email: ahmedmahgoub@mau.edu.eg

Received 7/11/2019; Accepted 15/12/2019

DOI: 10.21608/agro.2019.19247.1192

C2019 National Information and Documentation Center (NIDOC) 
El-Sarag et al. (2013) found that the $2^{\text {nd }}$ sowing date $\left(1^{\text {st }}\right.$ December) gave superiority of wheat grain yield and most of its components compared to sowing at Nov, 16 and Dec, 16. Meanwhile, Baloch et al. (2010) concluded that sowing wheat on October, 25 and November, 10 produced the highest number of tillers, spike length, plant height, 1000-grain weight and the grain yield, which subsequently decreased with successive sowing dates.

Blue green algae (also called Cyanobacteria) function as a biofertilizer due to the property of nitrogen fixation was increased grain yield by 10 $30 \%$ over the control (Mahato \& Sahu, 2017). Pimratch et al. (2015), found that Application of BGA resulted in significantly higher phosphorus and potassium in seeds compared with untreated control. However, due to the biological nature of BGA, the results obtained from fields may vary according to season, and their effect, compared to application of chemical fertilizers, may not be clear cut. Paudel \& Pradhan (2012), revealed that $\mathrm{N}$ content of the soil with BGA inoculated treatments was comparatively higher than application of compound NPK fertilizers. The utilization of biofertilizers as Blue green algae and biological nitrogen fixation technology can reduce usage of chemaical fertilizers and environmental pollution (Abd El-Lattief, 2012).

Biofertilizers are mixtures of microorganisms, essential plant nutrients and growth regulating substance (Bhardwaj et al., 2014; Shen et al., 2015). They improve soil physical and chemical properties, and promote plant growth, thus decreasing the need for inorganic fertlizers and reduce environmental pollution. Azotobacters were used for along time as biofertilizer for their nitrogen fixing ability and their role in phosphate solubilization and production of plant hormones. They also play a role in suppression of pathogens and increasing cereals yield (Das, 2019). In addition, many researchers showed the positive response of inoculation of wheat with Azotobacter and/or Azospirillum (Fayez \& Makboul, 1985; Tawfik \& Gomaa, 2005; Abbasdokht, 2008; Badr et al., 2009; Bahrani et al., 2010)

This study aimed to investigate the response of some wheat cultivars under different sowing dates, biofertilizer as blue green algae and microbein, regarding some agronomic, yield and yield components.

\section{Materials and Methods}

\section{Field experiments and soil properties}

The field experiments were conducted during 2016/2017 and 2017/2018 winter seasons at Fuka Research Station, Faculty of Desert and Environmental Agriculture, Matrouh Governorate (North West Coast of Egypt, $\mathrm{N}=31^{\circ} 04^{\prime}$, $\mathrm{E}=$ $\left.27^{\circ} 54^{\circ}\right)$. The experimental site is classified as Mediterranean climate which are presented in (Table 1)

TABLE 1. Climatic conditions during the two seasons of the experimental site.

\begin{tabular}{|c|c|c|c|c|}
\hline Month & Average temp. & Min temp. & Max temp. & Precipitation \\
\hline \multicolumn{5}{|c|}{$2016 / 2017$ season } \\
\hline November 2016 & $19.8^{\circ} \mathrm{C}$ & $11^{\circ} \mathrm{C}-20^{\circ} \mathrm{C}$ & $19^{\circ} \mathrm{C}-29^{\circ} \mathrm{C}$ & 16.10 \\
\hline December 2016 & $14.3^{\circ} \mathrm{C}$ & $7^{\circ} \mathrm{C}-17^{\circ} \mathrm{C}$ & $12^{\circ} \mathrm{C}-22^{\circ} \mathrm{C}$ & 16.30 \\
\hline January 2017 & $12.3^{\circ} \mathrm{C}$ & $3^{\circ} \mathrm{C}-13^{\circ} \mathrm{C}$ & $14^{\circ} \mathrm{C}-20^{\circ} \mathrm{C}$ & 12.84 \\
\hline February 2017 & $14.3^{\circ} \mathrm{C}$ & $7^{\circ} \mathrm{C}-13^{\circ} \mathrm{C}$ & $14^{\circ} \mathrm{C}-22^{\circ} \mathrm{C}$ & 6.31 \\
\hline March 2017 & $15.8^{\circ} \mathrm{C}$ & $9^{\circ} \mathrm{C}-14^{\circ} \mathrm{C}$ & $17^{\circ} \mathrm{C}-23^{\circ} \mathrm{C}$ & 5.41 \\
\hline April 2017 & $17.9^{\circ} \mathrm{C}$ & $5^{\circ} \mathrm{C}-17^{\circ} \mathrm{C}$ & $19^{\circ} \mathrm{C}-34^{\circ} \mathrm{C}$ & 0 \\
\hline May 2017 & $21.5^{\circ} \mathrm{C}$ & $10^{\circ} \mathrm{C}-22^{\circ} \mathrm{C}$ & $21^{\circ} \mathrm{C}-39^{\circ} \mathrm{C}$ & 0 \\
\hline \multicolumn{5}{|c|}{$2017 / 2018$ season } \\
\hline November 2017 & $18.0^{\circ} \mathrm{C}$ & $9^{\circ} \mathrm{C}-19^{\circ} \mathrm{C}$ & $19^{\circ} \mathrm{C}-27^{\circ} \mathrm{C}$ & 15.90 \\
\hline December 2017 & $16.2^{\circ} \mathrm{C}$ & $7^{\circ} \mathrm{C}-18^{\circ} \mathrm{C}$ & $14^{\circ} \mathrm{C}-25^{\circ} \mathrm{C}$ & 56.96 \\
\hline January 2018 & $14.2^{\circ} \mathrm{C}$ & $8^{\circ} \mathrm{C}-14^{\circ} \mathrm{C}$ & $13^{\circ} \mathrm{C}-21^{\circ} \mathrm{C}$ & 11.72 \\
\hline February 2018 & $16.9^{\circ} \mathrm{C}$ & $8^{\circ} \mathrm{C}-17^{\circ} \mathrm{C}$ & $16^{\circ} \mathrm{C}-27^{\circ} \mathrm{C}$ & 12.31 \\
\hline March 2018 & $17.9^{\circ} \mathrm{C}$ & $8^{\circ} \mathrm{C}-16^{\circ} \mathrm{C}$ & $18^{\circ} \mathrm{C}-35^{\circ} \mathrm{C}$ & 0.30 \\
\hline April 2018 & $19.7^{\circ} \mathrm{C}$ & $10^{\circ} \mathrm{C}-22^{\circ} \mathrm{C}$ & $20^{\circ} \mathrm{C}-34^{\circ} \mathrm{C}$ & 0 \\
\hline May 2018 & $22.4^{\circ} \mathrm{C}$ & $15^{\circ} \mathrm{C}-23^{\circ} \mathrm{C}$ & $22^{\circ} \mathrm{C}-42^{\circ} \mathrm{C}$ & 0 \\
\hline
\end{tabular}


Moreover, the experimental site soil (according to Chapman \& Pratt, 1961) had the following properties: Texture $=$ sandy (calcareous), $\mathrm{pH}=$ 8.1 , total organic matter $=0.70 \%, \mathrm{Ec}=3.3 \mathrm{dS} / \mathrm{m}$, $\mathrm{Ca}^{++}=35.4 \mathrm{meg} / \mathrm{L}, \mathrm{Mg}^{++}=15.2 \mathrm{meg} / \mathrm{L}, \mathrm{Na}^{+}=$ $49.4 \mathrm{meg} / \mathrm{L}, \mathrm{K}^{+}=1.1 \mathrm{meg} / \mathrm{L}, \mathrm{CO}_{3}^{--}=0.1 \mathrm{meg} / \mathrm{L}$, $\mathrm{HCO}_{3}^{-}=3.7 \mathrm{meg} / \mathrm{L}, \mathrm{Cl}^{-}=48.1 \mathrm{meg} / \mathrm{L}, \mathrm{SO} 4^{--}=$ $52.3 \mathrm{meg} / \mathrm{L}$ and $\mathrm{SAR}=11.6$ as an average of the two seasons.

\section{Treatment}

The aim of investigation was to evaluate the response of three wheat (Triticum aestivum, L.) i.e.; Misr 2, Giza 168 and Sids 12 cultivars under three sowing dates $\left(15^{\text {th }}\right.$ November, $30^{\text {th }}$ November and $15^{\text {th }}$ December ( and three treatments of biofertilizer: 1) Control (without adding biofertilizers) 2) Blue green algae (BGA) 3 ) Micobein (contain Psedomonnas sp., Azotobacter sp., Azospirillum sp.and B. megaterium).

Blue green algae (known commercially as Gorn 19, Vera Chema Company) with the recommendation of one spraying at 45 days from sowing at the rate of $240 \mathrm{~cm}^{3} / 360 \mathrm{~L}$ water/ha. BGA contain: $\mathrm{N}=15.4, \mathrm{P}=24.3, \mathrm{Ca}=1226, \mathrm{Fe}=7.38$, $\mathrm{Zn}=0.25, \mathrm{~K}=2162, \mathrm{Mg}=658.8, \mathrm{MN}=3.95$ and $\mathrm{Cu}=0.06 \mathrm{ppm}$. Also wheat grains were inoculated with microbein just before planting at the rate of $10 \mathrm{~kg} / \mathrm{ha}$. Plot size was $5.4 \mathrm{~m}^{2}$ (9 rows X $0.2 \mathrm{~m}$ between rows X 3.0 m row length). For nitrogen fertilization, control plots received $144 \mathrm{~kg} \mathrm{~N} / \mathrm{ha}$, while BGA and microbein plots received $96 \mathrm{~kg}$ $\mathrm{N} / \mathrm{ha}$, in the form of ammonium sulphate $(20.5 \mathrm{~N})$ added in two equal doses, the first at sowing and the second at 30 days later. Also, phosphors was added during soil preparation at the rate of $37.5 \mathrm{~kg}$ $\mathrm{P}_{2} \mathrm{O}_{5}$ /ha in the form of calcium monophosphate $\left(15.5 \% \mathrm{P}_{2} \mathrm{O}_{5}\right)$. Seeding rate for wheat cultivars was $96 \mathrm{~kg} / \mathrm{ha}$. Sprinkler irrigation during wheat growth period was added as needed.

\section{Experimental design and statistical analysis}

A split-split plot design with three replicates was used in both seasons. The main plots were devoted to three wheat cultivars and the sub plots were occupied by the three sowing dates whereas, the sub-sub plots were assigned to the three biofertilizer treatment. Data were subjected to the proper analysis according to Gomez \& Gomez (1984) using SAS (Statistical Analysis Systems) ver. 9.1.3 (2007). Means were compared using the least significant difference (LSD) value at 5\% level of probability.

\section{Recorded data}

At harvest, the following characters were recorded for each sub plot: Plant height $(\mathrm{cm})$, Number of spikes $/ \mathrm{m}^{2}$, Number of grains/spike, 100 grain weight (g), Biological yield (ton/ha), grain yield (ton/ha) and harvest index (\%) was calculated.

\section{$\underline{\text { Results and Discussion }}$}

\section{Plant height}

Data presented in Table 2 revealed significant variations in plant height among the investigated wheat cultivars. Cultivar Sids 12 had significantly tallest plants that reached, 89.73 and $85.20 \mathrm{~cm}$ for the first and second growing seasons, respectively. This might be due to genetic variability (Milad et al., 2016) resulting in significant differences between genotypes (durum and bread wheat).

Moreover, early sowing in November, 15 resulted in-significant increase in plant height, 82.19 and $81.70 \mathrm{~cm}$ for the two respective growing seasons. Furthermore, biofertilization using BGA significantly increased wheat plant height $(82.19 \mathrm{~cm})$ in the first season. It is evident that biofertilizers improve soil fertility and stimulate root growth in plants. In addition, they keep the soil in balanced conditions and consequently, nitrogen, potassium and phosphorus will be produced naturally (Abd-El Salam et al., 2014). Pimratch et al. (2015) reported similar results that application of BGA tended to increase plant height. Interaction between cultivars and biofertilizer treatments (Table 3 ) exerted a significant effect on plant height in the first season only. Using Sids 12 cultivar and BGA fertilizers gave the significantly tallest plant $(90.55 \mathrm{~cm})$, which might be due to genetic variability between cultivars and their response to environmental conditions.

\section{Number of spikes $/ \mathrm{m}^{2}$}

Number of spikes per unit area showed significant variation due to different cultivars in both growing seasons. Giza 168 cultivar recorded the highest number of spikes (350.00 and 394.16) followed by Misr 2 and Sids 12 in the first and second seasons, respectively. Sowing dates significantly influenced number of spikes $/ \mathrm{m}^{2}$ in both seasons (Table 2). Highest values for such trait (321.95 and 351.10) were obtained by early sowing in November 15, which lead to more time for vegetative growth period to give a higher number of tillers per unit area (Seleiman et al., 
2011; Bendidi et al., 2016). Additionally, data in (Table 2) indicated highly significant effect, on number of spikes $/ \mathrm{m}^{2}$, by applying BGA fertilizer in both seasons. BGA as fertilizer significantly increased number of spikes by 10.26 and $8.73 \%$ compared to control treatment. Data in Table 4 showed the interaction between cultivars, sowing dates and biofertilizer treatment for such trait in both study seasons. The highest number of spikes/ $\mathrm{m}^{2}$ (440.54, as an average of two seasons) was obtained by using Giza 168 and early sowing in November 15, with applying BGA fertilizer.

\section{Number of grains/spike}

The number of grains/spike was influenced by different cultivars in both seasons (Table 2). Sids 12 showed highest number of grains (55.67 and 54.86) in the first and second seasons, respectively. This might be due to the fact that Sids 12 is a long spiked cultivar. As for sowing dates, delaying sowing date to December 15, significantly decreased number of grains/spikes by (12.73 and $12.96 \%)$ compared to early sowing in November 15, in both seasons, respectively. This might be due to that late sowing shortened vegetative growth period and compelled wheat cultivars to complete life cycle earlier. Similar trend was observed by Xia et al. (2019) who found that delay sowing reduced number of grains per ear which led to reduction in grain yield. Three way interactions between cultivars, sowing dates and biofertilizer treatment, showed significant effect in both seasons (Table 4). Giza 168 cultivars suffered less reduction in number of grains/spike, under all fertilizer treatments, with delayed sowing from Nov, 15 to Dec, 15 compared to Misr 2 and Sids 12. That may be explained by the higher ability of Giza 168 to tolerant high temperature at grain development stage and maintain high fertility levels under heat stress (Milad et al., 2016).

\section{0 grain weight}

In the two seasons 2017 and 2018, significant difference were found between cultivars, sowing dates and biofertiliers where Sids 12 gave heaviest weight of grains (4.33 and 4.08g) compared to the other cultivars (Table 5). Meanwhile, data showed that delaying wheat sowing date from Nov, 15 to Dec, 15 reduced 100 grain weight by 6.40 and $7.31 \%$, in the $1^{\text {st }}$ and $2^{\text {nd }}$ seasons, respectively. It seemed that prevailing weather during growing period may play a role for growth improvement and grain filling which may reflect on grain yield (El-Metwally et al., 2012). Fayed et al. (2015) revealed that 1000 kernel weight of all studied cultivars were progressively decreased by delaying sowing dates. Furthermore, using BGA significantly increased 100 grain weight from 3.98 to $4.11 \mathrm{~g}$, as average of two seasons, compared to using microbein fertlilizer.

TABLE 2. Mean values of plant height, No. spikes $/ \mathrm{m}^{2}$, No. grains/spike and panicle weight of wheat in 2016/2017 and 2017/2018 seasons.

\begin{tabular}{|c|c|c|c|c|c|c|}
\hline \multirow{2}{*}{$\begin{array}{ll}\text { Treatments } & \text { Characters }\end{array}$} & \multicolumn{2}{|c|}{ Plant height (cm) } & \multicolumn{2}{|c|}{ No. spikes/m² } & \multicolumn{2}{|c|}{ No. grains/spike } \\
\hline & 2016/17 & 2017/18 & 2016/17 & $2017 / 18$ & $2016 / 17$ & $2017 / 18$ \\
\hline \multicolumn{7}{|c|}{ Cultivars } \\
\hline Misr 2 & 71.03 & 71.00 & 302.11 & 344.21 & 46.44 & 46.69 \\
\hline Giza 168 & 75.84 & 76.50 & 350.00 & 394.16 & 47.74 & 47.14 \\
\hline Sids 12 & 89.73 & 85.20 & 248.09 & 249.40 & 55.67 & 54.86 \\
\hline LSD $_{0.05}$ & 4.94 & 9.25 & 0.55 & 1.92 & 1.15 & 0.93 \\
\hline \multicolumn{7}{|c|}{ Sowing dates } \\
\hline Nov, 15 & 82.19 & 81.70 & 321.95 & 351.10 & 52.92 & 52.72 \\
\hline Nov, 30 & 77.88 & 74.40 & 299.79 & 331.59 & 49.98 & 49.30 \\
\hline Dec, 15 & 76.52 & 76.60 & 278.45 & 305.07 & 46.94 & 46.67 \\
\hline LSD $_{0.05}$ & 2.54 & 5.65 & 0.76 & 1.69 & 0.66 & 0.75 \\
\hline \multicolumn{7}{|c|}{ Biofertilizers } \\
\hline Control & 75.27 & 74.40 & 285.56 & 314.48 & 46.23 & 45.90 \\
\hline BGA & 82.19 & 78.90 & 314.87 & 341.96 & 53.74 & 52.86 \\
\hline Microbein & 79.14 & 79.30 & 299.77 & 331.33 & 49.88 & 49.94 \\
\hline LSD $_{0.05}$ & 2.17 & NS & 0.72 & 1.45 & 0.65 & 0.49 \\
\hline
\end{tabular}

NS: Not significant.

Egypt. J. Agron. 41, No. 3 (2019) 
TABLE 3. Mean values for plant height as affected by the interaction between wheat cultivars and biofertilizers in 2016/17 season.

\begin{tabular}{|c|c|c|c|}
\hline \multirow[b]{3}{*}{ Cultivars } & \multicolumn{3}{|c|}{$\begin{array}{c}\text { Plant height (2016/17) } \\
\text { (cm) }\end{array}$} \\
\hline & \multicolumn{3}{|c|}{ Biofertilizers } \\
\hline & Control & BGA & Microbein \\
\hline Misr 2 & 66.24 & 75.58 & 71.27 \\
\hline Giza 168 & 70.55 & 80.44 & 76.51 \\
\hline Sids 12 & 89.00 & 90.55 & 89.65 \\
\hline LSD $_{0.05}$ & \multicolumn{3}{|c|}{5.13} \\
\hline
\end{tabular}

Interaction between cultivars, sowing dates and biofertilizer treatment for 100 grain weight in 2017/2018 season, are presented in Table 6. Cultivars showed various response by using biofertilizers (BGA and microbein) at different sowing dates. Sids 12 cultivars indicated highest values $(4.40$ and $4.30 \mathrm{~g})$ by using BGA and microbein, respectively, at sowing on Nov, 15 . The response of Sids 12 at sowing on Dec, 15, with BGA application, compared to microbein, gave the highest response percentage (6.97) compared to sowing at Nov, $30(4.76 \%)$.

\section{Biological yield}

Mean values for biological yield, as influenced by wheat cultivars, sowing dates and biofertilizers are presented in Table 5. Sids 12 cultivar significantly surpassed the other two cultivars (14.90ton/ha) in the second season only. Moreover, sowing dates showed significant differences in both seasons. Early sowing at Nov, 15 significantly increased such trait from 13.37 for Dec, 15 to 14.50 ton/ha, as an average of two seasons. This might be due to elongated vegetative growth period of cultivars to produce higher value of biological yield. Furthermore, biofertilization using BGA significantly increased biological yield (10.17 and $11.34 \%$ ) compared to control in both seasons. ELBeltagy et al. (2016) concluded that inoculating wheat with cyanobacteria under $75 \%$ nitrogen increased dry weight of wheat plants and this result was not significantly different from those recorded by the treatment of $100 \%$ N. Also, Ghazal et al. (2018) found that inoculation with cyanobacteria generally encouraged the growth of wheat plants giving taller plants, higher no. of spikes, spike weight, straw yield, grain yield and 1000 grain weight.
Interaction between cultivars, sowing dates and biofertilizer treatment for biological yield was significant in 2017/2018 season only (Table 6). Cultivars showed various response using biofertilizers (BGA and microbein) at different sowing dates. Sids 12 cultivars gave highest values (16.30 and 15.90ton/ha) using algae and microbein, respectively, when sowing at Nov, 15. Misr 2 showed insignificant response to BGA or microbein additions at the different dates of sowing. However, Giza 168 responded significantly to microbein addition, only. In general, the response was negative with delaying sowing date.

\section{Grain yield}

Mean values for grain yield, as influenced by wheat cultivars, sowing dates and biofertilizers are presented in Table 5. Sids 12 revealed highest significant values (4.69 and 4.60ton/ha) for such trait in both seasons, respectively. Early sowing in Nov, 15 compared to delay sowing at Dec, 15 significantly increased grain yield from 4.08 and 4.04 to 4.48 and 4.50 ton/ha in the first and second seasons, respectively, indicating that delay sowing reduces the duration of both vegetative growth and grain development and consequently reducing grain yield. The accumulated heat units of the late sowing may be not sufficient for completing phenological stages of wheat growth and exerted such depression in growth and productivity of wheat plant.

Using BGA, compared to microbein, increased grain yield by 4.15 and 4.80 percent in both seasons, respectively. Paudel et al. (2012) revealed that BGA increased grain yield up to $7 \%-20.9 \%$ and straw yield up to $7.2 \%-18.1 \%$, respectively. Also, Mishra \& Pabbi (2004) found that yield increased by $12.3-19.5 \%$ on BGA inoculation in rice field. Prasad (2005) found 7.53-21.2\% increased in grain yield and $6.57-21.6 \%$ increased in straw yield with BGA inoculation.

As for the interaction between cultivars and sowing dates in second season, (Table 7) results indicated that cultivars responded differently to sowing dates, where Misr 2 and Sids 12 showed significant decrease in grain yield with delay in sowing beyond Nov, 15, whereas Giza 168 suffered significant decrease in grain yield when sown after Nov, 30. The cultivars*biofertilizers interaction (Table 8) indicated that Sids 12 showed similar response to addition of BGA or microbein, whereas both Misr 2 and Giza 168 yielded higher with BGA than microbein. 


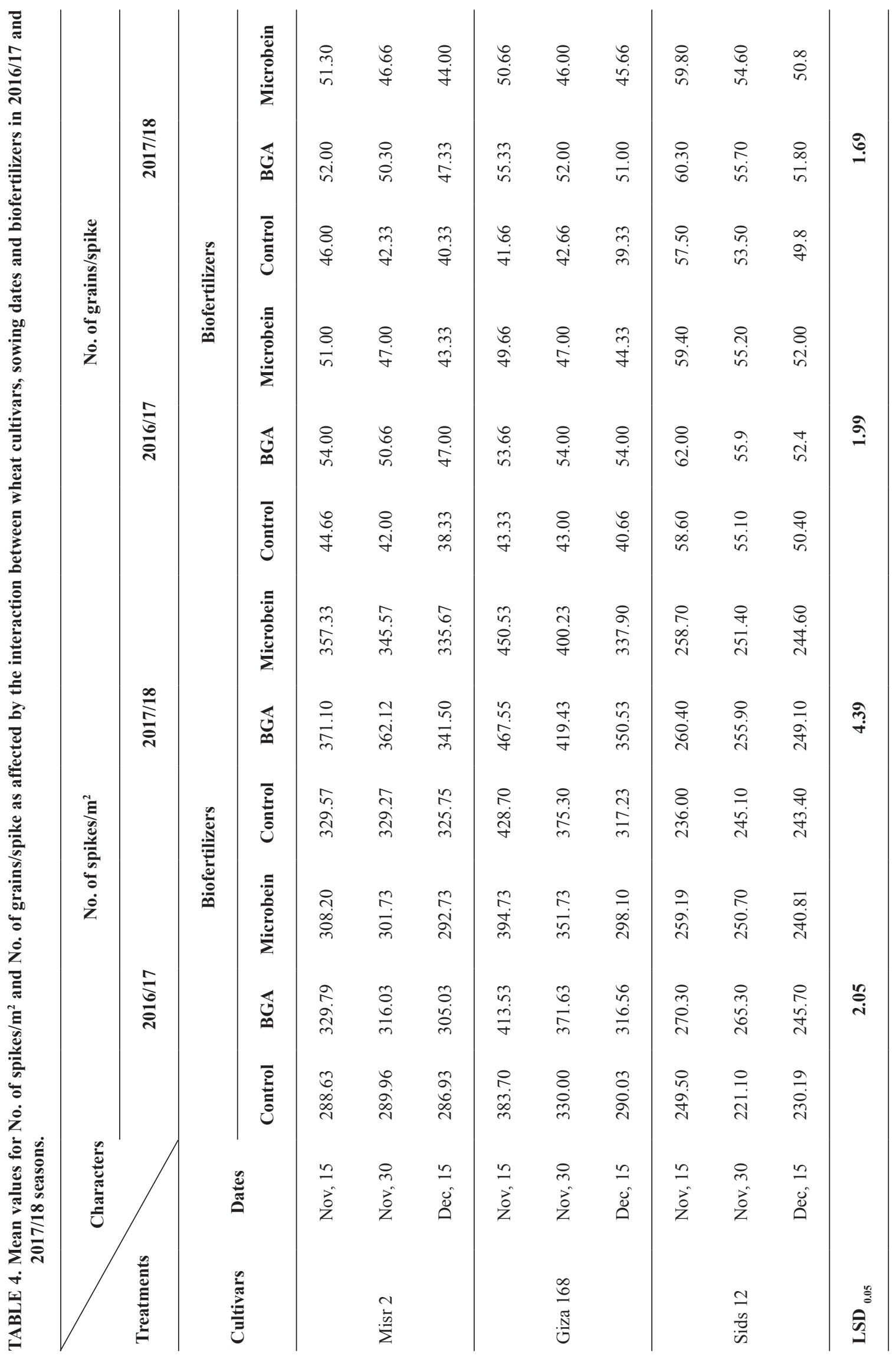

Egypt. J. Agron. 41, No. 3 (2019) 
TABLE 5. Mean values of 100 grain weight, biological yield, grain yield and harvest index of wheat in 2016/2017 and 2017/2018 seasons.

\begin{tabular}{|c|c|c|c|c|c|c|c|c|}
\hline \multirow[b]{2}{*}{ Treatments } & \multicolumn{2}{|c|}{$\begin{array}{l}100 \text { grain weight } \\
\text { (g) }\end{array}$} & \multicolumn{2}{|c|}{$\begin{array}{l}\text { Biological yield } \\
\text { (ton/ha) }\end{array}$} & \multicolumn{2}{|c|}{$\begin{array}{l}\text { Grain yield } \\
\text { (ton/ha) }\end{array}$} & \multicolumn{2}{|c|}{$\begin{array}{c}\text { Harvest index } \\
(\%)\end{array}$} \\
\hline & $2016 / 17$ & $2017 / 18$ & 2016/17 & $2017 / 18$ & $2016 / 17$ & $2017 / 18$ & $2016 / 17$ & 2017/18 \\
\hline \multicolumn{9}{|l|}{ Cultivars } \\
\hline Misr 2 & 3.88 & 3.90 & 13.57 & 13.47 & 4.13 & 4.15 & 30.33 & 30.80 \\
\hline Giza 168 & 3.89 & 3.91 & 13.28 & 13.37 & 4.08 & 4.15 & 30.67 & 31.02 \\
\hline Sids 12 & 4.33 & 4.08 & 15.13 & 14.90 & 4.69 & 4.60 & 30.96 & 30.92 \\
\hline $\operatorname{LSD}_{0.05}$ & 0.12 & 0.09 & NS & 1.04 & 0.11 & 0.15 & 0.28 & NS \\
\hline \multicolumn{9}{|l|}{ Sowing dates } \\
\hline Nov, 15 & 4.16 & 4.11 & 14.53 & 14.48 & 4.48 & 4.50 & 30.91 & 31.17 \\
\hline Nov, 30 & 4.04 & 3.96 & 14.03 & 13.93 & 4.33 & 4.37 & 30.80 & 31.31 \\
\hline Dec, 15 & 3.91 & 3.83 & 13.42 & 13.33 & 4.08 & 4.04 & 30.25 & 30.25 \\
\hline LSD $_{0.05}$ & 0.08 & 0.06 & 0.27 & 0.16 & 0.06 & 0.08 & 0.38 & 0.20 \\
\hline \multicolumn{9}{|l|}{ Biofertilizers } \\
\hline Control & 3.96 & 3.85 & 13.15 & 12.97 & 3.94 & 3.96 & 29.78 & 30.46 \\
\hline BGA & 4.13 & 4.09 & 14.64 & 14.63 & 4.57 & 4.58 & 31.36 & 31.37 \\
\hline Microbein & 4.02 & 3.95 & 14.19 & 14.13 & 4.38 & 4.36 & 30.81 & 30.91 \\
\hline LSD $_{0.05}$ & 0.04 & 0.06 & 0.33 & 0.30 & 0.06 & 0.07 & 0.21 & 0.20 \\
\hline
\end{tabular}

NS: Not significant.

Harvest index

Data revealed that harvest index was significantly influenced by studied factors in both seasons except for cultivars in the second season (Table 3). Sids 12 gave highest value (30.96\%), followed by Giza 168 (30.67\%) and Misr 2 (30.33\%). Meanwhile, early sowing at Nov, 15 showed highest values (30.91 and $31.17 \%$ ) for harvest index in both seasons, respectively. Biofertilization with BGA significantly increased harvest index (31.36 and $31.37 \%$ in both seasons, respectively) compared to microbein or control. This might be due to the increase in dry weight and attaining more photosynthetic matters to grain (Abd El-Lattief, 2012). Interaction between cultivars, sowing dates and biofertilizer treatment for harvest index, in both season, is presented in Table 7 . Non of the three cultivars showed significant response to BGA application at the different sowing dates. On the other hand, addition of microbein gave significant increase in harvest index at earlier sowing dates (Nov, 15 and 30) in Misr 2 and Giza 168 compared to Dec, 15 sowing date, while Nov, 30 was significantly superior to Nov, 15 in Sids 12 cultivar.
Regression analysis for grain yield and yield components $0 \mathrm{n}$ sowing dates showed a significant negative relationship in both seasons (Fig 1). The relationship were of high $\mathrm{r}^{2}$ values ranging from 0.81 to 0.99 , indicating that sowing date was the detrimental factor in the expression of those characters. The highest effect for delayed sowing was detected for no. of spikes $/ \mathrm{m}^{2}(-1.37$ and -1.40 for the first and second season, respectively) while, the least effect was estimated for 100 grain weight. Decrease in yield components, with different magnitudes, resulted in decrease in grain yield linearly and quadratically, where the quadratic effect was related primarily to the decrease in 100 grain weight.

\section{Conclusion}

In conclusion, the results of the present investigation showed that the use of biofertilizers such as BGA and microbein (nitrogen fixation organisms) are important in agriculture to reduce the application of chemical fertlizers $(33 \%)$ and maintain high grain yield, thus reducing environmental pollution and costs of production. 


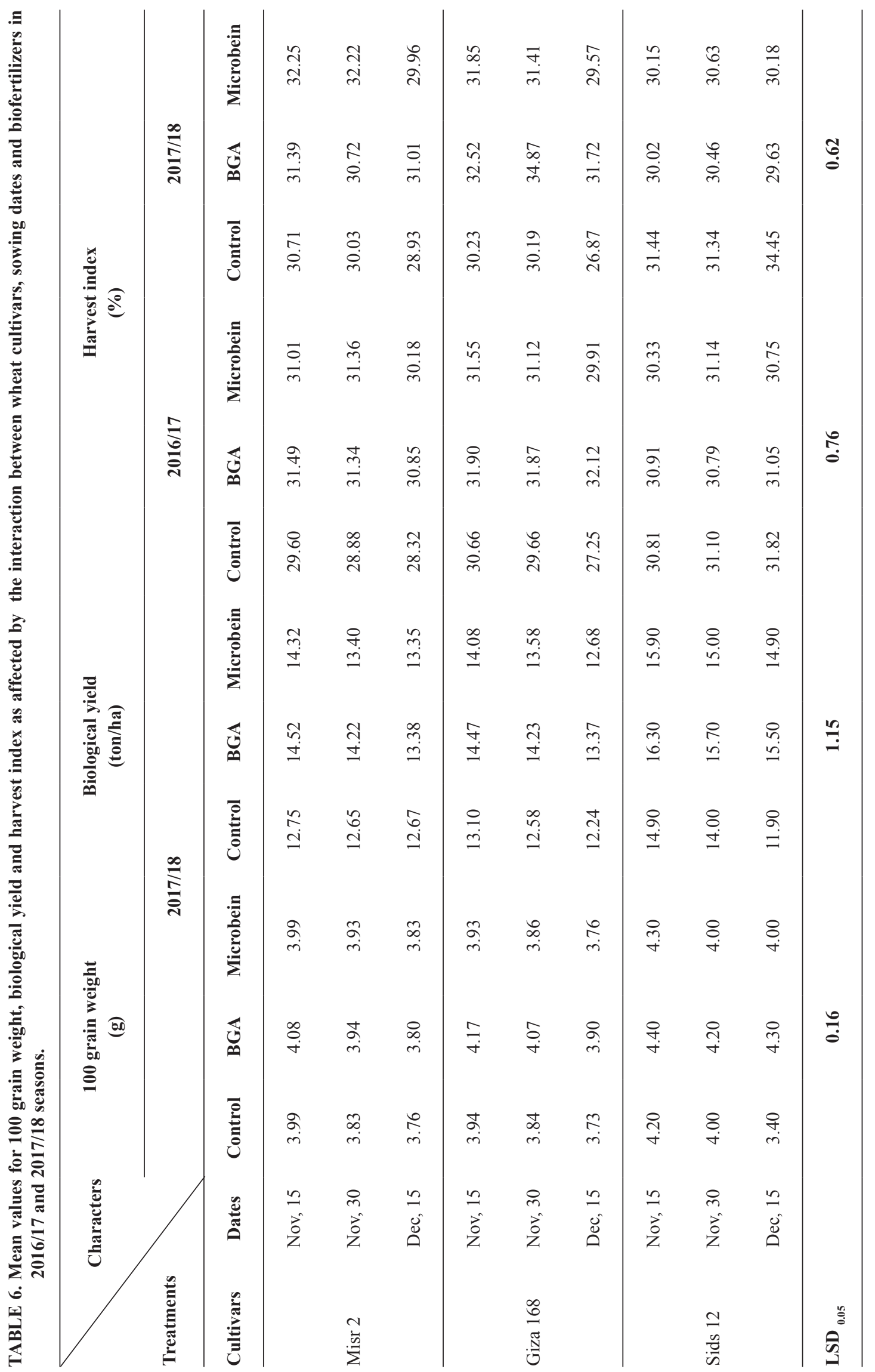

Egypt. J. Agron. 41, No. 3 (2019) 
TABLE 7. Mean values for grain yield as affected by the interaction between wheat cultivars, sowing dates in 2017/2018 season.

\begin{tabular}{|c|c|c|c|}
\hline \multirow[b]{2}{*}{ Cultivars } & \multicolumn{3}{|c|}{$\begin{array}{c}\text { Grain yield } \\
\text { (ton/ha) }\end{array}$} \\
\hline & Nov, 15 & Nov, 30 & Dec, 15 \\
\hline Misr 2 & 4.36 & 4.16 & 3.94 \\
\hline Giza 168 & 4.35 & 4.35 & 3.78 \\
\hline Sids 12 & 4.80 & 4.60 & 4.40 \\
\hline LSD $_{0.05}$ & & 0.17 & \\
\hline
\end{tabular}

TABLE 8. Mean values for grain yield and as affected by the interaction between wheat cultivars and biofertilizers in $2016 / 2017$ or $2017 / 2018$ season.

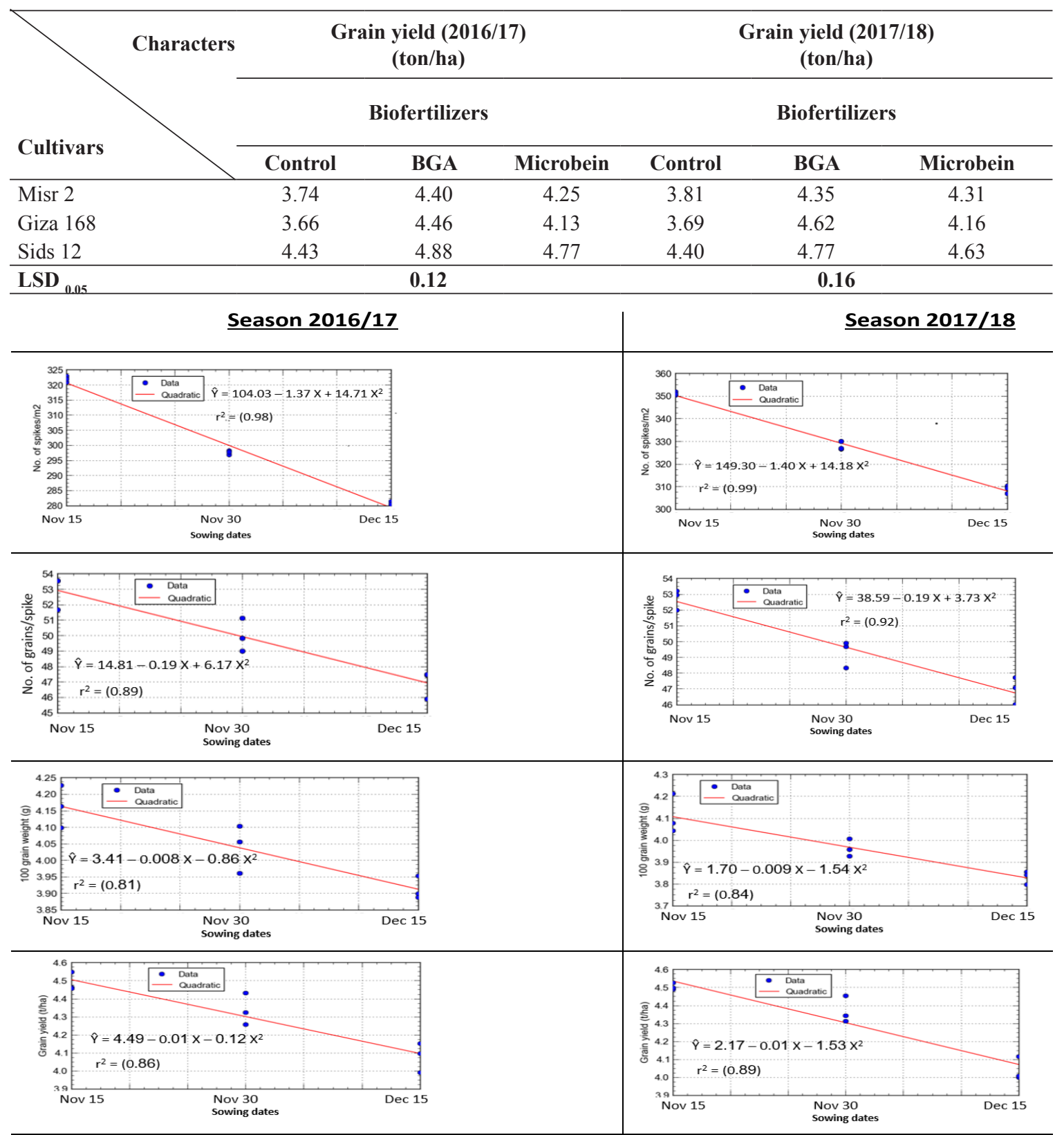

Fig. 1. Graphical representation of regression analysis of No. of spikes $/ \mathrm{m}^{2}$, No. of grains/spike, 100 grain weight and grain yield on sowing dates in 2016/2017 and 2017/2018 seasons. 


\section{References}

Abbasdokht, H. (2008) The study of Azotobacter chroococcum inoculation on yield and post harvest quality of wheat. International Meeting on Soil Land Management and Agroclimatology, Turkey, pp. 885-889.

Abd El-Lattief, E.A. (2012) Improving bread wheat productivity and reduce use of mineral nitrogen by inoculation with Azotobacter and Azospirillum Under Arid Environment in Upper Egypt. International Conference on Applied Life Sciences (ICALS2012), Turkey, September 10-12.

Abd-El Salam, K.M.H., Shaalan, A.M., El-Dalil, M.A.E. (2014) Effect of nitrogen fertilizer sources on grain yield, yield components and grain quality of rice. Alexandria Science Exchange Journal, 35, 304-313.

Badr, A. Elham, Ibrahim, O.M., El-Kramany, M.F. (2009) Interaction effect of biological and organic fertilizers on yield and yield components of two wheat cultivars. Egypt.J. Agron. 31(1), 17-27.

Bahrani, A., Pourreza, J., Hagh Joo, M. (2010) Response of winter wheat to co-inoculation with azotobacter and arbescular mycorrhizal fungi (AMF) under different sources of nitrogen fertilizer. AmericanEurasian J. Agric. \& Environ. Sci. 8(1), 95-103

Baloch, M.S., Shah, I.T.H., Nadim, M.A., Khan, M.I., Khakwani, A.A. (2010) Effect of seeding density and planting time on growth and yield attributes of wheat. J. Anim. Plant Sci. 20(4), 239-242.

Bendidi, A., Daoui, K., Kajji, A., Bouichou, L., Ben Bella, M., Ibriz, M., Dahan, R. (2016) Response of bread wheat to sowing dates and the genotypes in morocco. J. Exp. Agri. International, 14(6), 1-8.

Bhardwaj, D., Ansari, M.W., Sahoo, R.K., Tuteja, N. (2014) Biofertilizers function as key player in sustainable agriculture by improving soil fertility, plant tolerance and crop productivity. Microb. Cell Fact. 13(1), 66-76.

Chapman, H.D., Pratt, P.F. (1961) "Methods of Analysis for Soil, Plants and Waters", pp. 150152. Reverside Univ., California. Div. Agric. Sci., California, U.S.A.

Das, H.K. (2019) Azotobacters as biofertilizer. Adv.
Appl. Microbiol. 108, 1-43

Ehdaie, B., Waines, J.G. (2001) Sowing date and nitrogen rate effects on dry matter and nitrogen partitioning in bread and durum wheat. Field Crops Research, 73(1), 47-61.

El-Beltagy, A.E., Ghazal, F.M., El- Shinnawy, M.M.M., Mahmoud, Wafaa H., Salem, Gehan S. (2016) Potency of certain cyanobacterial strains on wheat grown in sandy and alluvial soils. J. Arid Land Stud. 26, 167-174.

El-Metwally, El-M.A., Hassanein, M.A., Hussein, M.M., El-Noemani, A.A., Keheal, H.K. (2012) Tritical (Triticosecale) yield as affected by sowing dates and NPK fertilizers in Egyptian new reclaimed sandy soils. J. Appl. Sci. Res. 8(4), 2412-2418.

El-Sarag-Eman, Ismaeil I., Ryad, I.M. (2013) Evaluation of some bread wheat cultivars productivity as affected by sowing dates and water stress in semiarid region. Asian J. Crop Sci. 5, 167-178.

FAO (2018) FAOSTAT. Available at:. http://www.fao. org/faostat/en/\#data/QC.

Fayed, T.B., El-Sarag, Eman I., Hassanein, M.K., Magdy, A. (2015) Evaluation and prediction of some wheat cultivars productivity in relation to different sowing dates under North Sinai region conditions. Annals of Agricultural Sciences, 60(1), 11-20.

Fayez, M., Emam, N.F., Makboul, H.E. (1985) The possible use of nitrogen fixing Azospirilum as biofertilizer for wheat plants. Egypt. J. Microbiol. 20(2), 199-206.

Ghazal, F.M., Mahdy, E.M., Abd EL-Fattah, M.S., EL-Sadany, A.Y., Doha, N.M.E. (2018) The use of cyanobacteria as biofertilizer in wheat cultivation under different nitrogen rates. Nature and Science, 16(4).

Gomez, K.A., Gomez, A.A. (1984) "Statistical Procedures for Agricultural Research", ( $\left.2^{\text {nd }} e d.\right)$, pp. 20-29 \& 359-387. John Wiley \& Sons, Inc., New York 10158, USA.

Ma, S.C., Wang, T.C., Guana, X.K., Zhang, X. (2018) Effect of sowing time and seeding rate on yield components and water use efficiency of winter wheat by regulating the growth redundancy and 
physiological traits of root and shoot. Field Crops Research, 221, 166-174.

Mahato, A., Sahu, R. (2017) Blue- green algal biofertilizer and growth response of rice plants. International Journal of Plant Sciences, 12(1), 6871.

Milad, S.I.M., Nawar, A.I., Shaalan, A.M., Eldakak, M., Rohila, J.S.R. (2016) Response of different wheat genotype to drought and heat stresses during grain filling stage. Egypt. J. Agro. 38(3), 369-387.

Mishra, U., Pabbi, S. (2004) Cyanobacteria: A Potential Fertilizer for Rice http:/www.ias.ac.in/resonance.

Paudel, Y. P., Pradhan, S. (2012) Effect of bluegreen algae on soil nitrogen. African Journal of Biotechnology, 11(61), 12472-12474.

Paudel, Y.P., Pradhan, S., Pant, B., Prasad, B.N. (2012) Role of blue green algae in rice productivity. Agric. Biol. J. N. Am. 3(8), 332-335.

Pimratcha, S., Butsat, S., Kesmala, T. (2015)Application of blue-green algae and mineral fertilizers to direct seeding lowland rice. Science Asia, 41, 305-314.

Prasad, R.C. (2005) Studies on screening and biology of some of the potential blue green algae (Cyanobacteria) as a source of biofertilizers from the rice fields of Bagmati and Narayani Zones of Nepal. Ph. D. Thesis, under Prof. B. N. Prasadsubmitted to Central Department of Botany, T.U. Kathmandu, Nepal.

Refay, Y.A. (2011) Yield and yield component parameters of bread wheat genotypes as affected by sowing dates. Middle-East J. Sci. Res. 7(4), 484489.
SAS Institute, Inc., (2007) SAS Technical Report SAS/ STAT Software: Changes and Enhancements User's Guide, Volume 2, Version 9.1.3, Fourth Edition, Cary, NC: SAS Institute, Inc.

Seleiman, M., Ibrahim, M., Abdel-Aal, S., Zahran, G. (2011) Effect of sowing dates on productivity, technological and rheological characteristics of bread wheat. J. Agro Crop Sciences, 2(1), 1-6.

Shaaban, A.S.A., Wahbi, A., Sinclair, T.R. (2018) Sowing date and mulch to improve water use and yield of wheat and barley in the Middle East environment. Agricultural Systems, 165, 26-32.

Shen, Z., Ruan, Y., Chao, X., Zhang, J., Li, R., Shen, Q. (2015) Rhizosphere microbial community manipulated by 2 years of consecutive biofertilizer application associated with banana fusarium, wilt disease suppression. Biol. Fert. Soils, 51(5), $553 \mathrm{e} 562$.

Tawfik, M.M., Gomaa, A.M. (2005) Effect of organic and biofertilizers on the growth and yield of wheat plants. Egypt .J. Agrci. Res. 2(2), 711-725.

Widdowson, F.V., Penny, A., Darby, R.J., Bird, E., Hewitt, M.V. (1987) Amounts of $\mathrm{NO}_{3}-\mathrm{N}$ and $\mathrm{NH}_{4}-\mathrm{N}$ in soil, from autumn to spring, under winter wheat and their relationship to soil type, sowing date, previous crop and $\mathrm{N}$ uptake at Rothamsted, Woburn and Saxmundham, 1979-85. J. Agric. Sci. Camb. 108, 73-95.

Xia, R.A.S., Wang Pei-ru, Xue Ling-zhu, LEI MiaoMiao, Xue Jian-fu, Gao Zhi-qiang, Yang Zhen-ping (2019) Optimization of sowing date and seeding rate for high winter wheat yield based on pre-winter plant development and soil water usage in the Loess Plateau, China. J. Integrative Agriculture, 18(1), 33-42. 


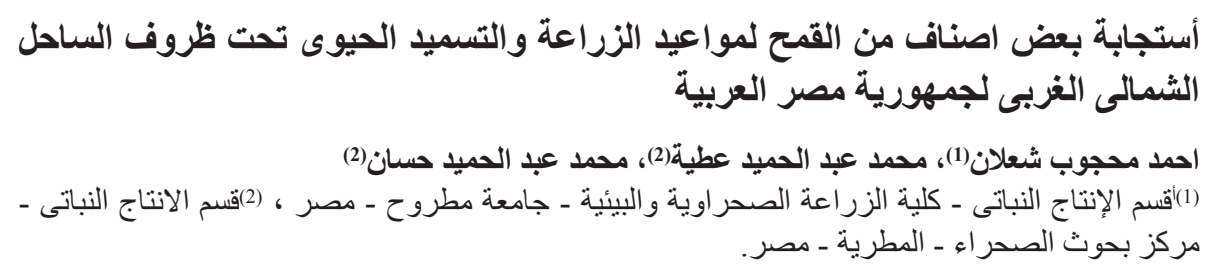

أجريت تجربتان حقليتان خلال الموسم الثنتوى 2016/2017 ، 2017/2018 بالمزر عة البحثية بكلية الزر اعة الصحر اوية

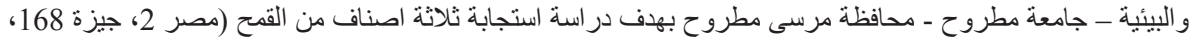

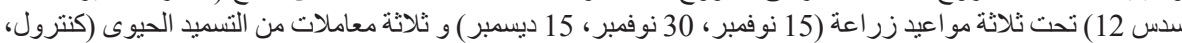

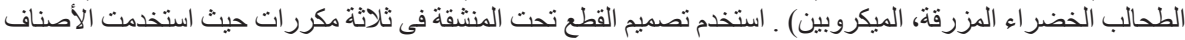

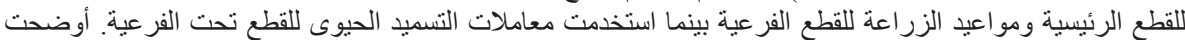

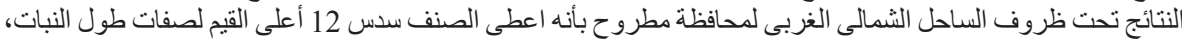

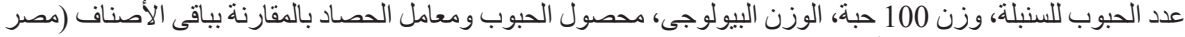

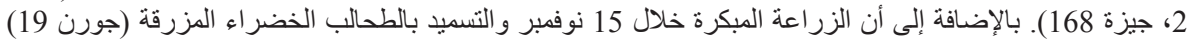

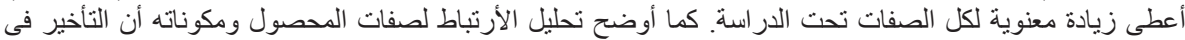

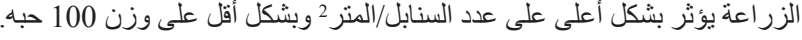

